No. 3896 , JULY 1, 1944

and development of centres and to consider applications for licences to set up such centres. The chairman and eight members are being appointed by the Minister, and four members each by the Milk Marketing Board, the National Farmers' Union, and collectively by the cattle breed societies.

\section{Therapeutic Trials Committee}

Vou. 2, Nos. 3 and 4 of the British Medical Bulletin is devoted to certain drugs and their modes of action. Dr. F. H. K. Green, of the administrative staff of the Medical Research Council, describes the work of that Council's Therapeutic Trials Committee. In response to representations by the Association of Chemical Manufacturers, the Medical Research Council organized in 1931 a scheme for the clinical testing of new remedies, and the Therapeutic Trials Committee was set up as a disinterested intermediary between the manufacturers and the medical profession, some medical men having been reluctant to carry out tests at the request of commercial firms. It was agreed that foreign as well as British remedies should be tried out and also the products of academic as well as of commercial laboratories. Manufacturers desiring trials by the Medical Research Council must agree to certain conditions. The composition and nature of the substance to be tested must be fully revealed to the Council; manufacturers must not, without the Council's permission, arrange for other independent trials, and the Council is interested only in new substances which have not been therapeutically tested.

When a substance is to be tested, arrangements are made with clinicians of high standing to make tests, usually at more than one hospital, and the Council reserves the right to decide whether the results, favourable or not, shall be published or revealed only to the manufacturer. If a clinician's results are published, they are published under the clinician's name as a report to the Therapeutic Trials Committee. Since the scheme was organized in 1931, more than forty new substances have been tested clinically. Outstanding examples are the classical papers embodying the results of clinical trials of 'prontosil rubrum', which established the therapeutic possibilities in man of the first sulphonamide drug, which had been discovered in Germany; some of the earliest controlled clinical tests of sulphanilamide; trials of stilkœstrol and other synthetic castrogenic agents. During the War clinical tests of penicillin have been organized and are still going on, and British-made equivalents of important foreign pharmaceutical products are being tested. The control of infections of wounds and burns is also being studied. Ultimately, says Dr. Green, it is at the bedside that the clinical value of any new remedy is decided; but it is evident that the manufacturer, the medical man and the patient all stand to gain by the excellent work of the Therapeutic Trials Committee.

\section{The Ray Society}

THE Ray Society was constituted at a meeting held on February 2, 1844. The report of the Council for the year 1943, which has just been circulated, states that it had been hoped to mark the centenary year by publishing a record of the Society's history; but the preparation of this had to be postponed until libraries are more accessible and times more favourable. It is regretted that it has not been possible to issue any publications during the year, the lamented death of Prof. W. M. Tattersall having prevented the completion of his volume on the British Mysidacea, which, however, is now being prepared for printing by Mrs. Tattersall. A work by Dr. F. E. Zeuner on "The Pleistocene Period, its Chronology, Climate and Faunal Successions" is now in the hands of the printers. The Society has not hitherto published any works dealing primarily with geology, but the Council considers that the subject-matter of Dr. Zeuner's book is so intimately connected with questions relating to the origin and distribution of the existing fauna and flora that it will be of great interest to many members of the Society. Reference is made to the loss suffered by the Society in the death of Sir David Prain, who had rendered important and long-continued service as a member of Council, as treasurer (1932-37), as a vice-president and as a trustee for the Society's investments. The annual general meeting for the current year having been omitted with the consent of the members, the present officers and Council will continue in office.

\section{Sensitivity of the Human Eye}

DR. Selig Hecrit, professor of biophysics at Columbia University, has recently made a tour of American colleges and universities, during which he has lectured to fifteen different Chapters of the Society of the Sigma Xi. His lecture gave some interesting data, arising from his own researches, on the sensitivity of the eye. Under the most favourable con. ditions, the smallest amount of light which the human eye can detect is 58-148 quanta, representing an energy of $2-6 \times 10^{-10}$ ergs. This 58-148 quanta is the amount of light falling on the cormea, but only about 10 per cent (5-14 quanta) of this is actually absorbed by the retina; the rest is lost by comeal reflexion (4 per cent), absorption by ocular media (50 per cent) and passing on beyond the retina (36 per cent). In the particular experiments described, this 5-14 quanta were absorbed by an area of retina which contained about five hundred receptor cells (rods). It seems reasonable to suppose, therefore, that each quantum was absorbed by a separate receptor cell. Chemical studies have shown that one quantum of light changes (bleaches) one molecule of visual purple. The conclusion reached is that we can see a light when the energy from it is sufficient to bleach one molecule of visual purple in each of 5-14 separate receptor cells.

\section{Wood Preservatives and Termite Attacks}

IN a recent pamphlet entitled "Effectiveness of Wood Preservatives in Preventing Attack by Termites" (U.S. Dept. of Agriculture. Circ. 683. By T. E. Snyder and J. Zetek. Washington: Gov. Printing Office. 10 cents) the opening paragraphs have a familiar ring to those acquainted with some of the more domestic troubles of early British rule in India and elsewhere in the tropies. "Wood has been classified," says the writer, "in the present global war as a critical structural material. Much of the wood to be utilized for the construction of the large number of necessary barracks and storage depots must be installed in the Tropics. Even in the event of a short War, past experience has shown that structures built to last for only short periods of service must be continued to be used long after the War is over. For the protection of wood from attack considerable research and investigation work 